\title{
BIZOMÁNYOSAN ÉRTÉKESÍTŐ ÉTREND-KIEGÉSZÍTŐKET GYÁR- TÓ VÁLLALATOK JELLEGZETES ELLÁTÁSI LÁNC TÍPUSAI
}

\author{
Szentesi Szabolcs \\ egyetemi tanársegéd, Miskolci Egyetem, Gépészmérnöki és Informatikai Kar, Logisztikai Intézet \\ 3515 Miskolc, Miskolc-Egyetemváros, e-mail: altszabi@uni-miskolc.hu \\ Illés Béla \\ egyetemi tanár, Miskolci Egyetem, Gépészmérnöki és Informatikai Kar, Logisztikai Intézet \\ 3515 Miskolc, Miskolc-Egyetemváros, e-mail: altilles@uni-miskolc.hu \\ Tamás Péter \\ egyetemi docens, Miskolci Egyetem, Gépészmérnöki és Informatikai Kar, Logisztikai Intézet \\ 3515 Miskolc, Miskolc-Egyetemváros, e-mail: alttpeti@uni-miskolc.hu
}

\begin{abstract}
Absztrakt
Az étrend-kiegészitőket gyártó vállalatok versenyképességük növelése érdekében elérendö stratégiai célokat (pl. költségcsökkentés, nagyobb rugalmasság, nagyobb kiszolgálási színvonal, fö tevékenységre koncentrálás stb.) határoznak meg, melyek elérésének fontos elemei az ellátási lánc kialakitásának módja és az értékesités módja. Napjainkban az értékesités módjának egyik elterjedt változata a bizományosi értékesitésü ellátási lánc hálózat kialakitása. A bizományosan értékesitö étrend-kiegészitöket gyártó vállalatok ellátási lánc kialakitásával a szakirodalom csekély mértékben foglalkozik, ezért ezen dolgozat az elöbb emlitett ellátási láncok jellegzetes kialakitási lehetöségeit vizsgálja.
\end{abstract}

Kulcsszavak: ellátási lánc, bizományosi értékesités, rendszerváltozatok

\begin{abstract}
Dietary supplement companies set strategic goals to be achieved in order to increase their competitiveness (eg cost reduction, greater flexibility, higher level of service, focus on core business, etc.), important elements of which are the way the supply chain is formed and the way they are sold. Nowadays, one of the common variants of the sales method is the establishment of a supply chain network with commission sales.There is little literature on the supply chain design of companies producing food supplements on a commission basis, so this dissertation deals with the typical design options of the aforementioned supply chains.
\end{abstract}

Keywords: supply chain, commission sales, system variants

\section{Bevezetés}

Az elmúlt évtizedekben az étrend-kiegészítők iránt jelentősen megnőtt a piaci kereslet, melyet a 2020 tól kialakult pandémiás helyzet tovább erősített (Sundmaeker, 2016). Magyarázható ez többek között azzal is, hogy az elmúlt fél évszázadban az élelmiszerekben egyértelmúen kimutatható volt 8-40\% közötti csökkenése a vas, a foszfor, a riboflavin (B2-vitamin), a fehérje, a kalcium és a C-vitamin tartalom tekintetében, amelyet az embereknek az egészségük megőrzése érdekében valamilyen formában pótolni kell (Halweil, 2007; Davis et al., 2004). 
Megállapítható, hogy az étrend-kiegészítő termékstruktúra rendkívül gyorsan és dinamikusan változik (Grand View Research Report ID 978-1-68038-919-7). Számos esetben az étrend-kiegészítők értékesítése az ellátási láncok egy speciális esetével valósul meg, vagyis bizományos értékesítési formában, így a termékek nem képezik a bizományos eladó tulajdonát (Elodie, Nantaporn, 2011). A bizományos értékesítési hálózatok müködtetésében szerzett gyakorlati tapasztalataink alapján megállapítható, hogy jelentős hiányosságok állnak fenn ezen a területen, melynek okán célként tüztük ki a bizományosan értékesítő ellátási láncok kialakításával kapcsolatos szakirodalom szisztematikus irodalomkutatással történő megismerését, a feltárt hiányosságok alapján meghatározni a bizományosan értékesítő étrend-kiegészítőket gyártó vállalatok jellegzetes ellátási lánc típusait. Külön figyelmet fordítunk az ellátási láncban lévő lejárt késztermék készletek újrahasznosítására is, amely számos esetben új anyagáramlási kapcsolatokat indukálhat.

\section{Irodalomkutatás alapján feltárt megállapítások}

Az áttekintő tanulmányok segítséget nyújthatnak az információk halmazában való eligazodásban, azonban a szerző szubjektuma, nem áttekinthető módszertana miatt a következtetések megbízhatósága sokszor kérdéses. A klasszikus összefoglaló tanulmányok - hívhatjuk öket irodalmi áttekintéseknek vagy beszámolóknak - gyakran nagyon hasznos háttér-információkat szolgáltatnak, mégis különböznek a belőlük kifejlődött szisztematikus irodalmi áttekintésektől abban, hogy nem egy előre meghatározott szigorú protokoll mentén haladnak, így többnyire nem reprodukálhatóak az eredmények. Emiatt ha előre meghatározott módszertan szerint a szakirodalomban fellelhető összes cikk kerül elemzésre, nem pedig szelektív módon egy adott kutatási témával kapcsolatban, az szélesebb körü betekintést enged a megoldandó problémába (Kamarási, Mogyorósy, 2015).

Jelen fejezet célja bemutatni a kutatási témakört és megismertetni azokat a szakirodalmi forrásokat és az azokban ismertetett kutatási eredményeket, amelyek segítenek ezen publikáció céljai megfogalmazásában. A szakirodalmi áttekintés több indexált publikációkat tartalmazó repozitóriumok segítségével készültek, mint a ScienceDirect, a Scopus és a Web of Science. A szakirodalmi kutatást az SLR módszerrel végeztük el, amely a következő lépésekből áll (Kamarási, Mogyorósy, 2015):

- Kutatási kérdések meghatározása (Ki mit csinált eddig? Ki végezte el, vagy publikálta a kutatást elsőként? Hol vannak a tudományos rések?).

- Kapcsolódó szakirodalom feltérképezése, elsősorban online adatbázisok segítségével.

- Találatok redukálása, releváns közlemények kiválasztása és elolvasásukkal a fö kutatási irány meghatározása (extra kulcsszavak meghatározása, szerzők alapján, dátum alapján, stb.).

- A közlemények feldolgozási és analizálási módszerének kidolgozása.

- Főbb tudományos áttörések és eredmények megfogalmazása.

- Tudományos rés vagy szük keresztmetszet meghatározása.

Bizományosi értékesítésről akkor beszélünk, ha a megbízó nem közvetlenül a vevők részére értékesít, hanem a termékeit bizományi szerződés alapján átadja egy másik félnek (a bizományosnak), és a vevők részére már ő értékesít. Jogi nyelven a bizományi szerződés alapján az egyik szerződő fél ellenérték fejében köteles a másik szerződő fél javára, de a saját nevében szerződést kötni harmadik személlyel (Elodie, Nantaporn, 2011; Zhihui et al., 2017; Jun, Yunzeng, 2010).

A megbízó és a bizományos között megbízási, addig a bizományos és a vevő között adásvételi szerződés jön létre. A bizományosnak a szerződésben rögzített megbízás teljesítéséért bizományi díj jár, feltéve, ha az adásvételi szerződést is teljesítették. A díj magában foglalja a bizomány ellátásával 
rendszerint együtt járó költségeket, többször a bizományba adás fejében a bizományos saját szállítási logisztikai rendszerét kihasználva, a szállítási disztribúciós költségeket is magára vállalja.

A felek a szerződésben rögzített időszakonként számolnak el úgy, hogy az adott időszakról a bizományos fogyásjelentést küld a megbízó részére, a megbízó a bizományosnak, ennek alapján számlázza le az eladott termékeket. Így a bizományosnak ezen értékesítése nem igényel finanszírozási fedezetet, hiszen az árukat nem előre kell megvásárolnia, hanem csak a már eladott tételeket kell kifizetnie (Jun, Yunzeng, 2010; Abolfazl et al., 2019).

A versenyképességük növelése érdekében a vállalatok elérendő stratégiai célokat (pl. költségcsökkentés, nagyobb rugalmasság, nagyobb kiszolgálási színvonal, fő tevékenységre koncentrálás stb.) határoznak meg, melyek tovább bonthatóak logisztikai célokra (Agnieszka, 2006). Ezen célok elérésének egyik eszköze lehet a bizományosi értékesítési hálózat kialakítása (Chikán, 1999; Körmendi, Pucsek, 2009; Lynch, 2000; KPMG Consuling Kft., 2003). Ellátási láncokról lévén szó, az értékteremtő - termelési, szolgáltatási, elosztási logisztikai folyamat nem csak vállalati határokon belül, hanem azokat átívelően valósul meg, ezért szükséges a partnerkapcsolatok nézőpontjának bevonása is.

A bizományosi készletek kezelésével általában a VMI rendszer (Vendor Managed Inventory) foglalkozik (Mishra, Raghunathan, 2004; Siraj et al., 2016). Definíció szerint a VMI egy együttmüködési megoldás a megrendelő és beszállítója között, amelynek célja, hogy optimalizálja a termék elérhetőségét a megrendelö és a beszállító legalacsonyabb költségszintje mellett. A beszállító átvállalja a készletek operatív kezelését a közösen lefektetett teljesítménycéloknak megfelelően, amelyet folyamatosan ellenőriznek és felülvizsgálnak a folyamatos fejlesztés elősegítése érdekében (Breite, Koskinen, 2007). A terület irodalmának elemzésénél első körben a következő kulcsszavak és fontosabb kombinációik keresését végeztem el:

- supply / ellátás,

- consignment / bizományi áru,

- contract/ szerződés,

- expiration date / minőségmegőrzési idő,

- seller / eladó,

- VMI / Vendor Managed Inventory / szállító által kezelt készlet.

Az adatbázisokban egyszerü keresést alkalmaztunk, ahol mindösszesen elöször két, aztán több keresőszót adtunk meg, amelyek kombinációit és találati eredményeit az 1. táblázat tartalmazza.

$\mathrm{Az}$ 1. táblázatban látható, hogy az eredeti kulcsszavak keresését szükséges volt szükíteni a „cím, absztrakt, kulcsszavak" területére annak érdekében, hogy a kutatott témához jobban illeszkedő keresési eredményt kapjunk. Ezután az egyes kulcsszavak keresési eredményei már kellően releváns találatokat eredményeztek. Ezután az egyes kulcsszavakra kapott találatokat egyetlen egy keresésbe integráltuk, a „minőségmegőrzési idő” kifejezés kivételével, mivel az arra kapott eredmények irreleváns publikációkat eredményeztek.

Az 1. táblázatban szereplő repozitóriumok keresési találatait összevontuk, így végeredményként 816 közleményt elemeztünk. Ebben a tekintetben megállapítható, hogy a publikációs adatbázisokban szereplő cikkek jelentős átfedést tartalmaznak, ugyanakkor a megjelent cikkek számában tapasztalható növekedési tendenciát ez nem befolyásolja.

A publikációk megjelenésének időbeli alakulását az 1. ábra szemlélteti, amelynél évről-évre a növekvő tendencia tapasztalható. 
1.táblázat. Kulcsszavak találatszáma a Scopus-ban, Web of Science-ben és a ScienceDirect-ben [Forrás: Saját szerkesztés]

\begin{tabular}{|c|c|c|c|c|c|c|c|c|c|c|c|c|c|c|c|c|c|c|}
\hline \multirow[b]{2}{*}{ 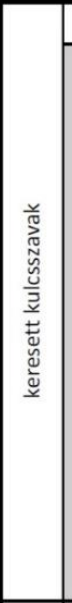 } & \multicolumn{6}{|c|}{ Scopus } & \multicolumn{6}{|c|}{ Web os Science } & \multicolumn{6}{|c|}{ ScienceDirect } \\
\hline & 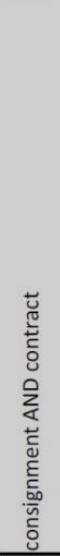 & 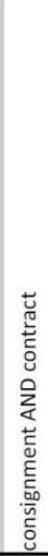 & 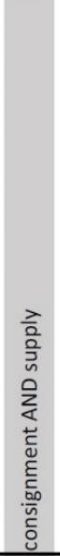 & 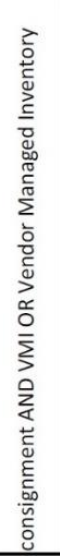 & 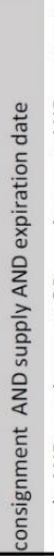 & 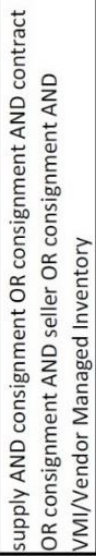 & 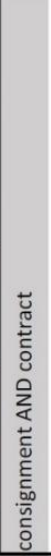 & 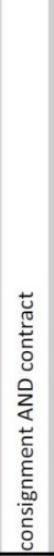 & 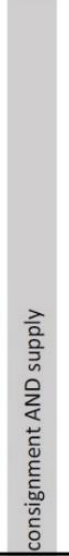 & 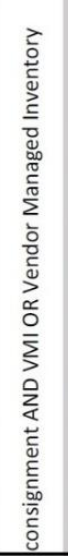 & 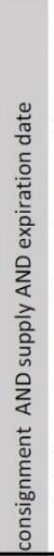 & 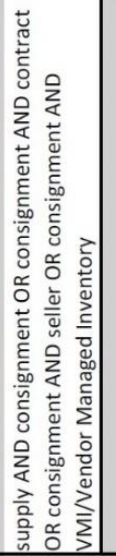 & 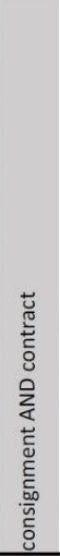 & 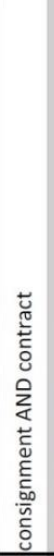 & 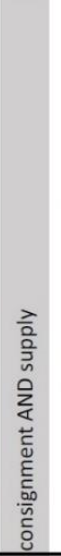 & 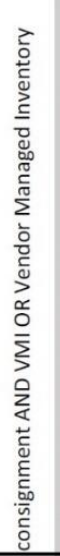 & 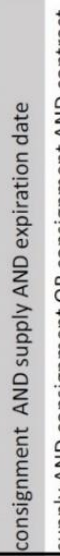 & 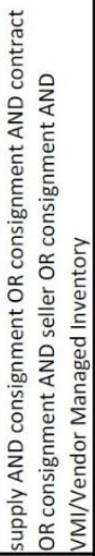 \\
\hline 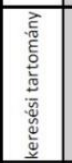 & 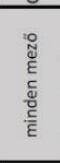 & 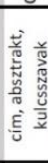 & & 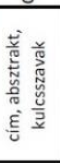 & 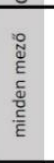 & 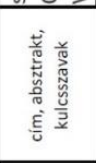 & 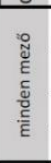 & & & 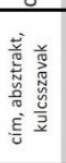 & 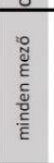 & 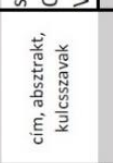 & 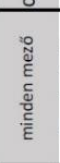 & & & 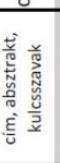 & 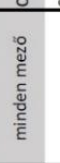 & 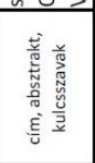 \\
\hline 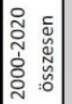 & 1211 & 153 & 353 & 83 & 24 & 418 & 158 & 150 & 292 & 103 & 1 & 309 & 1130 & 36 & 76 & 32 & 43 & 89 \\
\hline 2000 & 3 & 1 & 4 & 1 & 0 & 4 & 0 & 0 & 0 & 0 & 0 & 0 & 26 & 0 & 0 & 0 & 1 & 0 \\
\hline 2001 & 3 & 2 & 4 & 0 & 0 & 5 & 2 & 2 & 1 & 0 & 0 & 2 & 26 & 0 & 0 & 0 & 1 & 0 \\
\hline 2002 & 2 & 1 & 5 & 1 & 0 & 7 & 1 & 1 & 4 & 1 & 0 & 5 & 27 & 0 & 3 & 1 & 0 & 3 \\
\hline 2003 & 9 & 5 & 7 & 1 & 0 & 12 & 2 & 2 & 4 & 1 & 0 & 5 & 40 & 0 & 1 & 1 & 3 & 1 \\
\hline 2004 & 12 & 6 & 11 & 2 & 0 & 15 & 2 & 2 & 4 & 1 & 0 & 4 & 46 & 0 & 0 & 0 & 4 & 0 \\
\hline 2005 & 14 & 6 & 8 & 1 & 0 & 11 & 0 & 0 & 1 & 1 & 0 & 1 & 35 & 0 & 0 & 0 & 0 & 0 \\
\hline 2006 & 21 & 4 & 8 & 0 & 0 & 11 & 1 & 1 & 3 & 0 & 0 & 3 & 28 & 0 & 0 & 0 & 0 & 0 \\
\hline 2007 & 27 & 5 & 10 & 4 & 0 & 13 & 2 & 2 & 3 & 1 & 0 & 4 & 41 & 0 & 0 & 0 & 0 & 0 \\
\hline 2008 & 44 & 7 & 11 & 3 & 0 & 17 & 2 & 2 & 5 & 3 & 0 & 6 & 49 & 1 & 2 & 1 & 1 & 2 \\
\hline 2009 & 46 & 2 & 14 & 2 & 0 & 17 & 3 & 2 & 7 & 1 & 0 & 7 & 42 & 1 & 4 & 1 & 1 & 4 \\
\hline 2010 & 79 & 16 & 25 & 8 & 0 & 31 & 9 & 9 & 16 & 7 & 0 & 17 & 47 & 3 & 2 & 2 & 2 & 3 \\
\hline 2011 & 51 & 7 & 13 & 2 & 1 & 17 & 8 & 8 & 11 & 0 & 1 & 13 & 48 & 3 & 4 & 1 & 2 & 5 \\
\hline 2012 & 62 & 4 & 16 & 2 & 0 & 17 & 7 & 7 & 14 & 1 & 0 & 14 & 56 & 3 & 5 & 0 & 3 & 6 \\
\hline 2013 & 81 & 8 & 25 & 7 & 2 & 26 & 4 & 4 & 14 & 6 & 0 & 14 & 52 & 2 & 7 & 3 & 2 & 8 \\
\hline 2014 & 73 & 7 & 18 & 8 & 1 & 21 & 12 & 11 & 18 & 9 & 0 & 19 & 88 & 4 & 6 & 6 & 4 & 9 \\
\hline 2015 & 70 & 11 & 24 & 2 & 0 & 26 & 9 & 9 & 22 & 10 & 0 & 23 & 73 & 3 & 6 & 2 & 0 & 6 \\
\hline 2016 & 65 & 8 & 25 & 9 & 2 & 28 & 12 & 11 & 27 & 11 & 0 & 27 & 79 & 1 & 5 & 2 & 4 & 5 \\
\hline 17 & 96 & 10 & 35 & 12 & 1 & 39 & 17 & 16 & 33 & 19 & 0 & 34 & 89 & 2 & 8 & 3 & 4 & 9 \\
\hline 18 & 103 & 8 & 24 & 3 & 3 & 25 & 12 & 11 & 19 & 6 & 0 & 21 & 65 & 1 & 2 & 1 & 4 & 2 \\
\hline 2019 & 144 & 17 & 35 & 11 & 7 & 37 & 26 & 25 & 40 & 14 & 0 & 42 & 82 & 6 & 14 & 6 & 1 & 15 \\
\hline 2020 & 206 & 18 & 31 & 4 & 7 & 39 & 27 & 25 & 46 & 11 & 0 & 48 & 91 & 6 & 7 & 2 & 6 & 11 \\
\hline
\end{tabular}




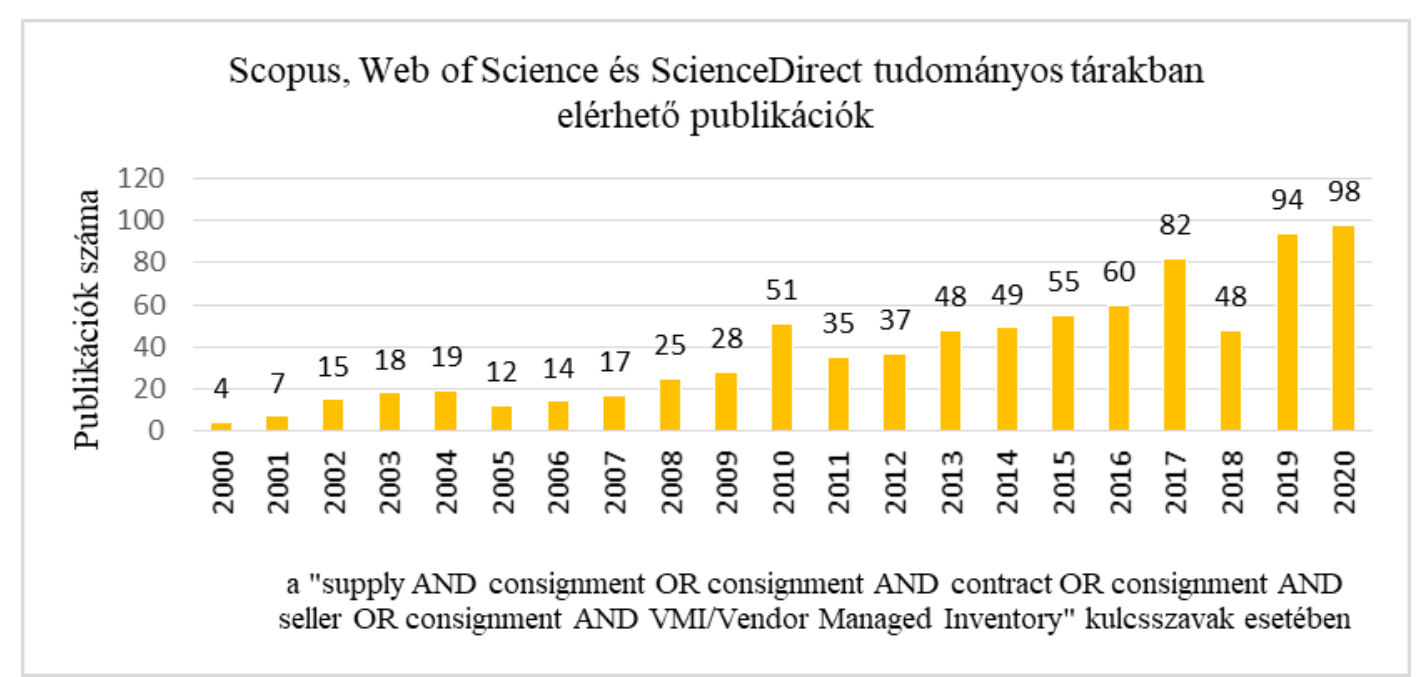

1.ábra. Témához kapcsolódó publikációk száma a megjelenési évek szerint [Forrás: Saját szerkesztés]

A szisztematikus irodalomkutatás eredményeként lehatárolt 816 cikket feldolgozva, fókuszálva a legkiemelkedőbb szerzőkre (hivatkozások száma, megjelenés éve, stb.) és legtöbbet idézett publikációkra a következő összefoglaló elemzés került elkészítésre. Az 1999-ig kapott találatok a kutatási témához nem kapcsolódtak, mivel a bizományosi értékesítés jellemzően a 2000 évek után vált ismertté, kezdett elterjedni. Megállapításra került, hogy a témával 2004-ben foglalkoztak elsőként mélyrehatóan, amely tanulmányban a bizományosi értékesítésủ ellátási lánc teljesítményét vizsgálták. Yunzeng és szerzőtársai 2004-es értekezésükben megállapították, hogy a bizományosi értékesítésű ellátási lánc és a benne lévő egyes cégek teljesítménye nagymértékben függ a keresleti ár rugalmasságától és a kiskereskedők részesedésétől (Yunzeng et al., 2004). Hesham és Ahmed 2017-ben konkrétan azt vizsgálták, hogy az ellenőrzési hibák hogyan befolyásolják egy bizományosi beszállító és több vevő ellátási láncrendszerének költségeit (Hesham, Ahmed, 2017). Hemmati és szerzőtársai 2017-ben a bizományosi értékesítésen alapuló modellben azt feltételezik, hogy a kereslet lineárisan érzékeny a készletek szintjére és az eladási árra. A cél olyan változók meghatározása, amelyek maximalizálják a teljes nyereséget. Az optimális megoldás megtalálását pontos numerikus megoldási eljárásban látják (Hemmati et al., 2017). Teyarachakul és szerzőtársai 2007-ben fontos kérdésnek tekintették, hogy a bizományosi raktárban lévő azon termékeket, amelyek forgási sebessége mégsem éri el a minőségmegőrzési idő végét, arra árengedményt érdemes-e eszközölni, vagy át kell-e csoportosítani azokat, továbbá feltételezik, hogy a piaci keresletet befolyásolják a promóciós erőfeszítések (Teyarachakul et al., 2007). Wei és Jianbin 2012-ben arról publikálnak, hogy a bizományosi értékesítésnél készletezési szempontból a bizományba adónak kétlépcsős problémát kell megoldania: először a szerződés feltételeit kell meghatározni, majd a kiválasztott szerződés feltételei szerint dönt a kiskereskedelmi árról és a szállítási mennyiségről (Wei, Jianbin, 2012).

A bizományosi szerződéseket sok iparágban széles körben alkalmazzák. Az ilyen szerződések szerint az elemeket egy kiskereskedőnél értékesítik, de a szállító a készlet teljes tulajdonát képezi, amíg a fogyasztók meg nem vásárolják a termékeket, ami után a bizományos kiskereskedő cég a tényleges eladott egységek alapján jutalékkal csökkentve fizet a bizományba adó szállítónak. Fontos vizsgálni, hogy a kiskereskedők közötti verseny hogyan befolyásolja az ellátási lánc döntéseit és a nyereséget a különféle szállítmányozási megállapodások, nevezetesen a bizományosi értékesítésủ megállapodás és 
a megvásárolt készlettel rendelkező szállítási szerződés alapján. Általában a bizományosi értékesítés keretei között eladott termékek, jóval nagyobb haszonkulcsot eredményeznek a kiskereskedőknek (Elodie, Nantaporn, 2011). Egy ilyen megállapodás népszerüsége folyamatos vitákkal jár azzal kapcsolatban, hogy ki irányíthatja az bizományos készletet a kiskereskedőnél, a szállító vagy a kiskereskedő. Azon bizományosan értékesítésủ ellátási láncokat vizsgálva, ahol egy bizományba adó gyártó vállalat látja el a bizományosokat termékkel, ott általában a termék piaci kereslete ár-érzékeny. Két különféle szállítmányozási rendszert különböztethetünk meg bizományos értékesítésnél és hasonlítunk össze: az első lehetővé teszi a kiskereskedőnek, hogy kezelje az ellátási lánc önmagánál lévő leltárát, a kiskereskedelmi árral együtt és kiskereskedő által kezelt szállítmánykészlet. A második rendszer átadja a jogot a bizományba adónak, hogy döntsön a készletről, a termékek árával együtt és a kiskereskedőnek küldendő szállítmánykészletről (Jun, Yunzeng, 2010). Több kutatás is rámutat mindkét rendszer sztochasztikus jellegére (Zhihui et al., 2017; Abolfazl et al., 2019; Yunzeng et al., 2004). A gyógyszeripari ellátási láncok elosztási logisztika aspektusainál a bizományos eladónál minőségmegőrzési idő miatt beragadt termékek újrahasznosításával csekély mértékben foglalkozik a szakirodalom, mivel a gyógyszer veszélyes hulladéknak számít, így a műanyag tárolóedények az - étrend-kiegészítőkkel ellentétben - egyszerü tisztítás után nem újrahasznosíthatóak (Országgyülési Hivatal, 2020). Wang és csapata 2004-ben a bizományosi értékesítési csatorna kiskereskedelmi áráról és a szállítási mennyiségekről értekezik a bizományosi elosztás területén. Megállapították, hogy mind a csatorna teljesítménye, mind az egyes cégek teljesítménye kritikusan függ a keresleti ár rugalmasságától és a kiskereskedők részesedésétől. Ezzel megállapítást nyert, hogy a bizományosi értékesítésű hálózatok egyik alappillére az, hogy a kiskereskedők nagyobb hasznot realizálnak a bizományosi termékeken, mint a hagyományosan készletre halmozott termékeken (Wang et al., 2004). Zavanella és Zanoni 2009-ben egy eladóból és több bizományosból álló elosztási hálózatot vesznek alapul és azt vizsgálják, hogy egy adott VMI politika sikeres stratégiát jelenthet-e mind a bizományos mind a szállító számára. Az elmúlt években a vállalatok megerősítették bizományosi szerződéseiket, sőt készleteik kezelését is. Ebből a célból az eladó által kezelt készlet (VMI) érdekes megközelítést képvisel a készlet figyelemmel kísérésében és ellenőrzésében, amelyet a legtöbb vállalat fontolgat bevezetni. A publikációban vizsgálják továbbá a VMI-irányelvet, a bizományosi készletek miként jelenthet sikeres stratégiát mind a vevő, mind a szállító számára. Bizományba adóként az eladó garantálja, hogy a bizományosi raktárában tárolt mennyiséget egy maximális és egy minimális szint között tartják (Zavanella, Zanoni, 2009). Li S. és csapata 2009-ben megállapították, hogy a bizományosi szerződések sok iparágban széles körben alkalmazott módszere. Egy olyan egyedi modellt fejleszt ki, amely azt feltételezi és akkor alkalmazható, ha olyan terméket értékesítünk az ellátási láncban, amely kockázat semleges és a kereslet eloszlása nagyon enyhe. Megállapítja, hogy ebben az esetben a decentralizált ellátási lánc tökéletesen koordinálható (Li et al., 2009). Daniela A. és Maria G. 2005-ben tanulmányoznak néhány komplex disztribúciós tervezési problémát, amely magába foglalja az elhelyezést, a raktározást, a szállítást és a készletre vonatkozó döntéseket. Egyik lehetséges megoldásként a problémára a Perl és Daskin modellt javasolják (Daniela, Maria, 2005). Claassen és csapata 2008-ban azt vizsgálták, hogy milyen előnyeit tapasztalják meg az érintettek a VMI-nek, valamint milyen sikertényezők vagy előfeltételek szükségesek az eredményes alkalmazáshoz. A bizományba adó számára a legfontosabbnak feltételezték, hogy termelését a valós vevői igény alapján tudják kivitelezni, ezáltal a pontos keresleti adatok ismeretében képes lesz az ingadozások kisimítására és feladatainak proaktív módon való elvégzésére (Claassen et al., 2008). Zanoni, Jaber és Mazzoldi 2014-ben egy egyedi ellátási lánc modellt mutat be az összehangolt készlet-utánpótlás döntésekhez a VMI rendszer keretei között, amely kétszintű ellátási lánc rendszer alapján valósít meg, egy bizományba adóval és egyetlen bizományossal (Zanoni et al., 2014). Chen és 
szerzőtársai 2010-ben egy vertikálisan elkülönített elosztási rendszer összehangolásának problémájával foglalkozik bizományosi értékesítés esetén kétszintü elosztási láncoknál. Megfogalmazzák a profitmaximalizálási problémát és egyensúlyi elemzést végeznek kooperatív és nem kooperatív körülmények között. Ezt követően javaslatot tesznek egy jövedelem-megosztási rendszerre (Chen et al., 2010). Bieniek 2018-ban a bizományosi értékesítésről értekezik, ahol a piaci kereslet additív, lineárisan árfüggő és bizonytalan. A bizonytalan visszatérési magatartás figyelembevétele a bizományosi szerződésben egy additív véletlen keresleti keretrendszerben a kockázatelemzés vizsgálatát végzik el és arra keresnek választ, hogy a vevői hozam bizonytalansága és más modellparaméterek hogyan befolyásolják a döntési változókat (Bieniek, 2018). Hariga és szerzőtársai 2013-ban egy olyan szállítói láncot vizsgálnak, amely egy bizományba adóból és több bizományosból áll kétszintű ellátási láncból áll. Az ellátási lánc VMI-szerződés alapján működik, amely meghatározza a kiskereskedők készletszintjének korlátjait. Az eladó ciklusidejének és a vevők egyenlőtlen megrendelési ciklusainak szinkronizálásának problémáját egy olyan egész számú, nemlineáris program kidolgozásával kezelik, amely a tárolás korlátozásai mellett minimalizálja a közös releváns készletköltségeket (Hariga et al., 2013). Zahran és szerzőtársai 2017-ben a szakirodalomban nagy számban fellelhető két-szintủ ellátási lánctól eltérően egy háromszintű ellátási lánc modellt vizsgál, amely a bizományba adóból, a bizományosból és a vevőkből állnak. Több koordinációs esetet vizsgál meg, ám itt sem jelenik meg a bizományosok közötti közvetlen anyagáramlás lehetősége és a vevőkkel a központi vállalat kapcsolata (Zahran et al., 2017).

Az irodalomkutatás során egyértelmüvé vált, hogy számos kutató foglalkozott a bizományosi ellátási láncok kialakításával, müködtetésének optimalizálásával, ugyanakkor ez idáig nem kerültek feltárásra ezen ellátási láncok típusai, így azon változatok sem, melyek tartalmazzák a bizományos értékesítők közötti anyagáramlási lehetőséget, valamint a bizományosoknál felhalmozott a - gyártás során újrahasznosítható - anyagok gyüjtési rendszerét.

\section{Bizományosan étékesítő ellátási láncok típusainak feltárása}

A bizományosan értékesítő étrend-kiegészítőket gyártó vállalatok ellátási lánca három modellből építhető fel, nevezetesen a beszerzési, a disztribúciós, valamint a visszaszállítási modell képez kapcsolatot a központi logisztikai és gyártó üzemmel. A modellváltozatok tekintetében feltételeztük, hogy a gyártás és bizományba kihelyezés egy központi telephelyről történik, valamint a szállítás valamennyi esetben ingajáratok formájában valósul meg (Szentesi et al., 2021). Az publikációban feltárásra kerülő ellátási lánc változatok alapvetően abban különböznek a jellegzetes ellátási lánc változatoktól, hogy a bizományos értékesítés következtében lehetőség van a bizományosok közötti anyagáramlásra, valamint a minőségmegőrzési idő leteltét követően a központi telephelyre - újrahasznosítási célból - való visszaszállításra is. Továbbá fontos specifikum lehet, hogy a készletek alakulását nem az értékesítést végző, hanem a bizományba adó szabályozza. 


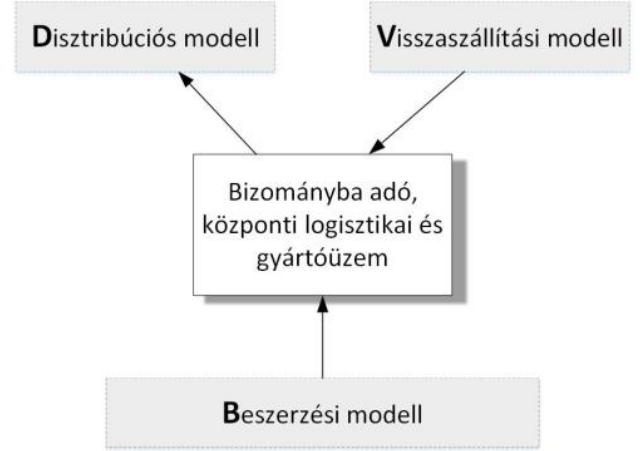

2. ábra. Bizományosi ellátási lánc szakaszolása [Forrás: Saját szerkesztés]

A következökben ezen modellek feltárt változatai kerülnek ismertetésre.

\section{Beszerzési modellek ismertetése:}

A 3. ábrán látható öt darab beszerzési modell változatainál a jelölések tekintetében egységes jelölésrendszert alkalmaztunk, ahol:

- $A B_{i}$ : az i. beszállító $(\mathrm{i}=1,2 \ldots \mathrm{n})$,

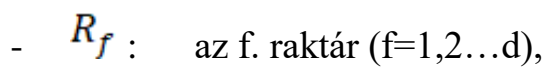

- $E_{h}$ : a h. beszállító csoport raktár $(\mathrm{h}=1,2 \ldots \mathrm{g})$,

- EK: központi beszállítói raktár.

\section{B1}

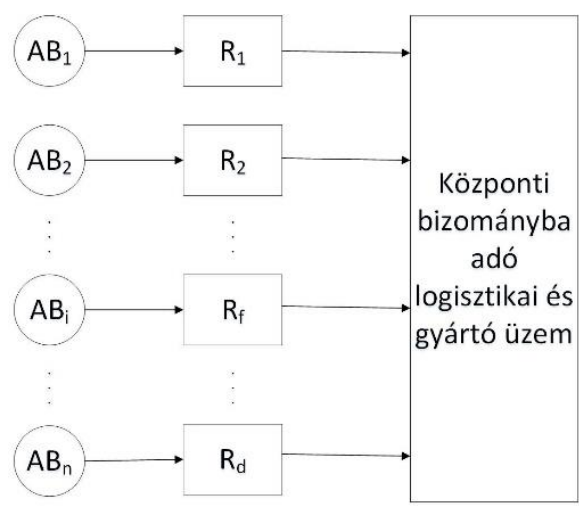

B2

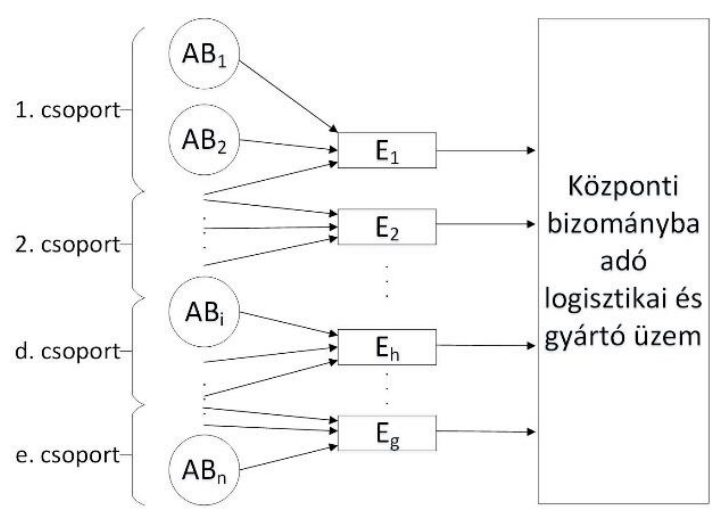


B3

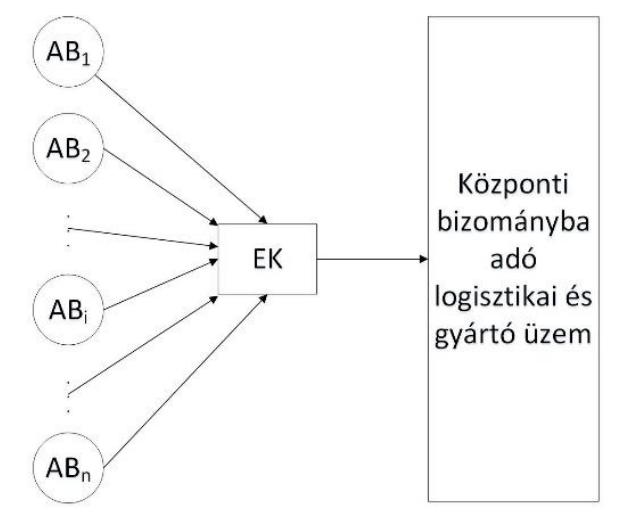

B4

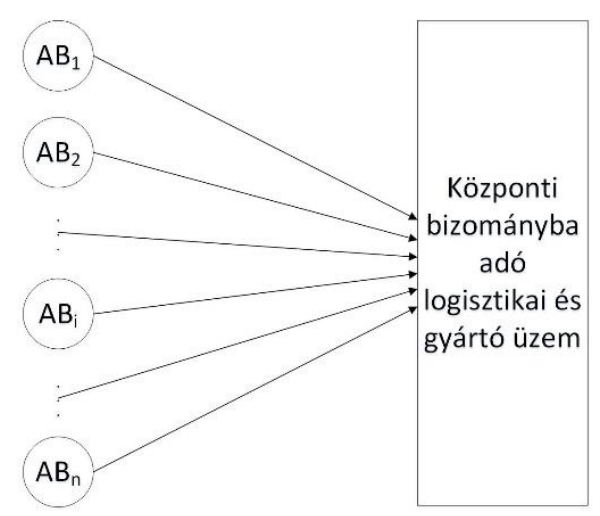

\section{B5}

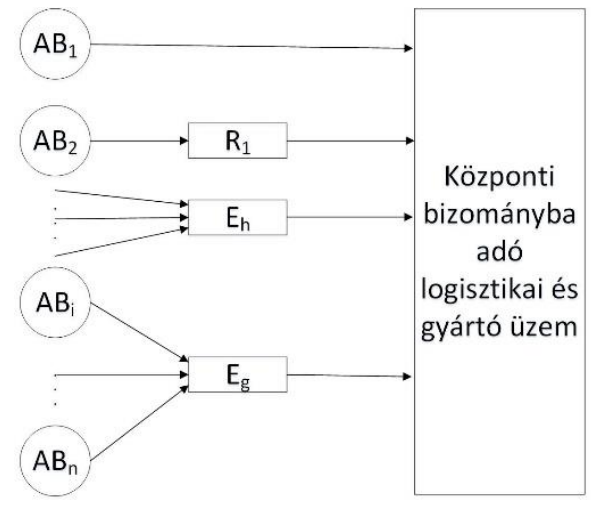

\section{3.ábra. Beszerzési modell változatok [Forrás: Saját szerkesztés]}

- B1: Ennél a modellnél, minden egyes beszállító külön egyedi raktárral rendelkezik és minden egyes beszállító a saját raktárán keresztül tartja a kapcsolatot a központi bizományba adó-gyártó üzemmel (egyedi, decentralizált raktározás). A modell előnye, hogy a beszállítók a raktározási problémákat saját maguk tudják kezelni, ugyanakkor hátránya a rendszernek, hogy sok raktárat kell megépíteni, fenntartani és üzemeltetni.

- B2: Ennél a beszállítói modellnél a beszállítók bizonyos szempontok alapján (elhelyezkedés, termékstruktúra, stb.) egy adott raktárhoz vannak rendelve, vagyis egy-egy raktárhoz beszállítók adott csoportja tartozik (csoportos raktározás). Ebben az esetben egy adott raktárat több beszállító használ közösen, ugyanakkor a raktárak száma kevesebb, mint a B1 modell esetén volt. Ez összességében a müködtetésnél költségmegtakarítást jelenthet.

- B3: Ezen típusú beszállítói modell esetén minden egyes beszállító egy központi raktárba szállít be (centralizált, központi raktározás). A központi raktárat a beszállítók közösen használják, a raktár megfelelő müködése érdekében komplex anyag és információáramlási kapcsolat szüksé- 
ges a központi raktár és a beszállítók között. Előnye, hogy csupán egy raktár müködtetését kell megvalósítani, ugyanakkor hátránya, hogy az összes beszállítói igényt kezelni kell tudni.

- B4: Ezen modell esetén a beszállítók közvetlenül a központi bizományba adó logisztikai és gyártó üzembe szállítják be a termékeiket (közvetlen beszállítás). A beszállítóknál nincsen raktározási tevékenység, ugyanakkor a központban megvalósuló raktározási tevékenységgel kell a folyamatos vevői igényeket kielégítő termelési tevékenységet megvalósítani. Ez egy fejlettebb anyag- és információáramlási kapcsolatot igényel, mind a beszállítók mind a gyártók között.

- B5: Ezen típusú beszállítói modell esetén az előző négy modell vegyes felhasználásából épül fel (vegyes beszállítási rendszer). Vannak olyan beszállítók, akik közvetlenül szállítanak be, vannak olyan beszállítók, akik saját raktárán közvetlenül szállít be és vannak olyan beszállítók, amelyek különböző csoportokba kerülnek beosztásra és ezek a csoportok egy-egy raktárat használnak a központtal tartott anyagáramlási folyamatnál.

A beszerzési modellváltozatok (B1-B5) univerzális modellek, amelyek más területen (pl. jármüipar, gyógyszeripar, stb.) is alkalmazásra kerülhetnek.

Központi bizományba adó logisztikai és gyártóüzem felépítése:

A 4. ábra a központi bizományba adó logisztikai és gyártóüzem jellegzetes felépítését, valamint az objektumok közötti anyagáramlási kapcsolatot szemlélteti.

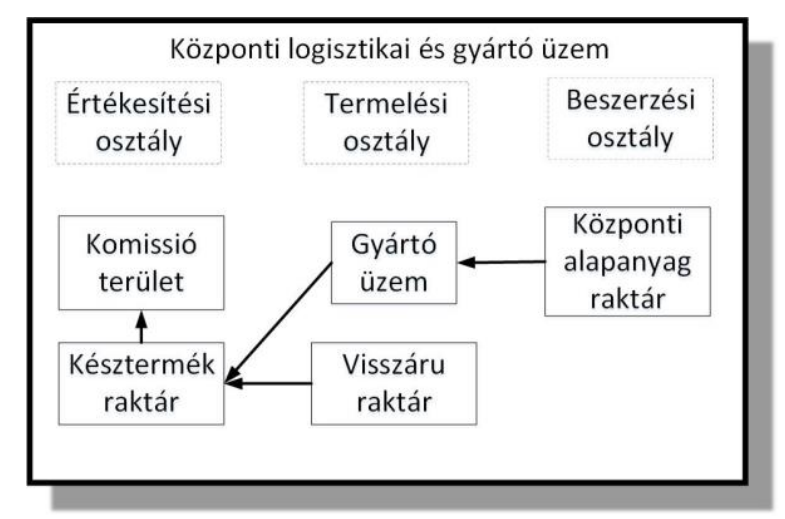

4.ábra. Központi logisztikai és gyártó üzemen belüli objektumok [Forrás: Saját szerkesztés]

Az 4. ábrán használt jelölések tartalma:

- Központi alapanyagraktár: A beszállítók a beszerzésért felelős osztály megrendelése alapján szállítják be a késztermék elkészítéséhez szükséges alapanyagot, mely a termelési igények alapján felhasználásra kerül. Elmondható, hogy ezen a területen „First Expired First Out” (továbbiakban: FEFO) elven történik a raktározás és az alapanyag kiadás a gyártó üzemnek. A FEFO elv az árucikkek lejárati idején alapul, olyan módon, hogy az az alapanyag vagy termék kerül ki elsőként a raktárból, amelynek a legkorábban jár le a minőségmegőrzési ideje.

- Gyártó üzem: A gyártó üzemben töltik meg a kapszulákat a különböző receptúrák alapján homogenizált alapanyagokkal, ahol a kapszulázást követően dobozolják és címkézik a termékeket. A következő lépés a termék átadása a késztermék raktárnak.

- Késztermék raktár: Jellemzően a késztermékraktárban is FEFO elv alapján, előre definiált készletezési mechanizmus(ok) figyelembevételével történik a raktározás.

- Komissiózó terület: Ezen a részlegen komissiózzák, majd csomagolják a hiánypótlásként - a bizományosok részére - kiküldendő készterméket. 
- Visszáru raktár: A bizományosoktól visszaérkezett nem lejárt termékek ebbe a részlegbe kerülnek, melyek a késztermék raktárba kerülnek át.

\section{Disztribúciós modellek ismertetése:}

Az 5. ábra disztribúciós modell változatoknál a jelölések tekintetében egységes jelölésrendszert alkalmaztunk, ahol:

- $V_{k}: \quad$ az k. vevő $(\mathrm{k}=1,2 \ldots \mathrm{o})$,

- $R_{f}: \quad$ az f. raktár $(\mathrm{f}=1,2 \ldots \mathrm{d})$,

- $E_{h}$ : a h. disztribúciós csoport raktár $(\mathrm{h}=1,2 \ldots \mathrm{g})$,

- EK: központi disztribúciós raktár,

- $B i z_{j}$ : a j. bizományos (j=1,2...m).

Az 5. ábrán látható modelleknél 3-féle színű nyíl található. A fekete színủ nyilak az alapmodell anyagáramlását jelölik, melynek további kiegészített változatai piros és zöld színű nyíllakkal kerültek jelölésre. Ezen túlmenően képezhető valamennyi típus integrált változata is.

\section{D1, D2, D3, D1-D3}

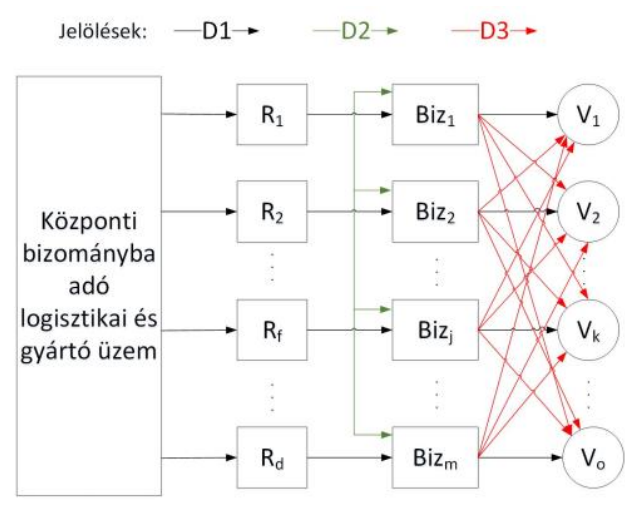

\section{D7, D8, D9, D7-D9}

Jelölések: $-\mathrm{D} 7 \rightarrow-\mathrm{D} 8 \rightarrow \longrightarrow \mathrm{D} 9 \rightarrow$

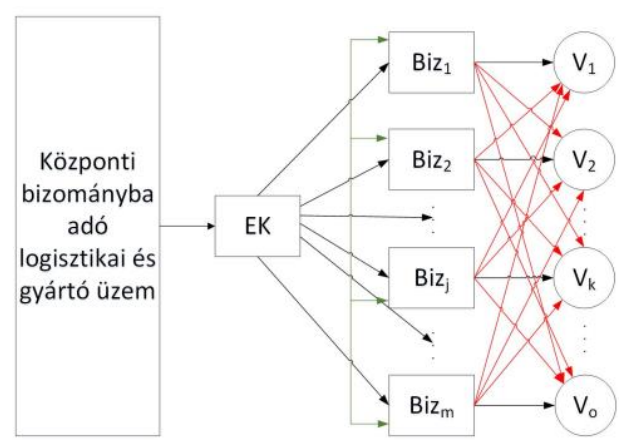

\section{D4, D5, D6, D4-D6}

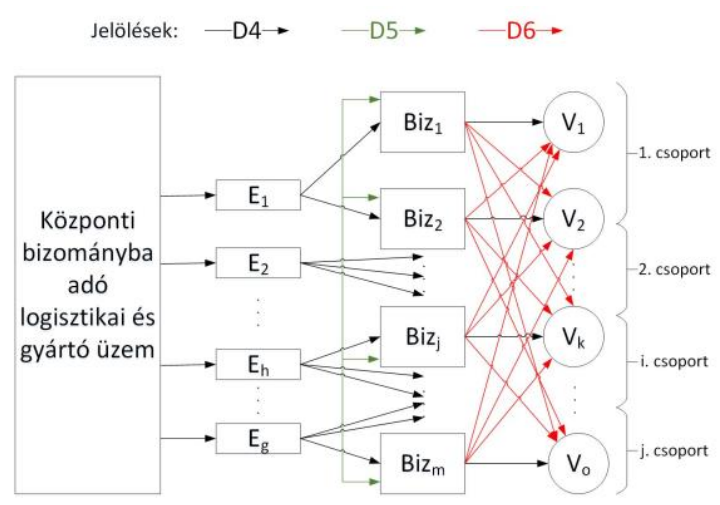

D10, D11, D12, D10-D12

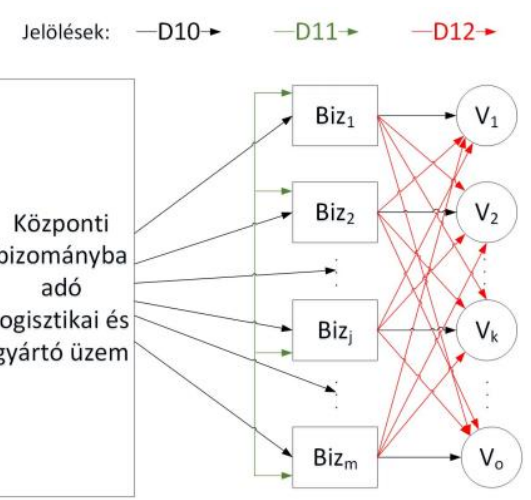




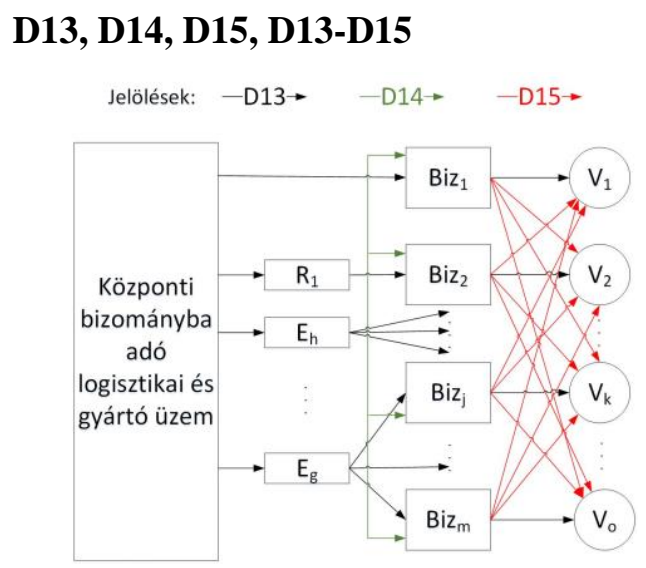

\section{5. ábra. Disztribúciós modell változatok [Forrás: Saját szerkesztés]}

- D1, D2, D3, D1-D3: Ezen típusú disztribúciós modelleknél, minden egyes bizományoshoz egyedi raktár van hozzárendelve és ezen keresztül kapja a készlet pótlásokat a központi bizományba adótól (egyedi, decentralizált raktározás). A modell előnyei, hogy a bizományosok egy külön a számukra fenntartott raktárból gyorsan megkaphatják a szükséges termékeket, ugyanakkor hátránya a rendszernek, hogy számos raktárat kell megépíteni és/vagy fenntartani, üzemeltetni. A D1 alapmodellben a bizományosok között nincs anyagáramlás és a bizományosoknak egyedi vevőik vannak. Az alapmodell D2 kiegészítésével a bizományosok között lehetőség van az anyagáramlás megvalósítására. Az alapmodell D3 kiegészítésében az bizományosok vevői kapcsolatrendszere kombinálható A D1-D3 modell a D1 alapmodell és kiegészítéseinek összes anyagáramlási kapcsolatait tartalmazza.

- D4, D5, D6, D4-D6: Ezen típusú disztribúciós modellek esetén a bizományosok bizonyos szempontok alapján (elhelyezkedés, termékstruktúra, stb.) bizonyos bizományosok egy adott raktárhoz vannak rendelve, vagyis egy-egy raktárhoz bizományosok adott csoportja tartozik (csoportos raktározás). Egy adott raktárból több bizományos ellátása is történik. A raktárak száma kevesebb, mint a D1-D3 modellek esetén volt, ez összességében a működtetésnél költségmegtakarítást jelenthet. A D4 alapmodellben a bizományosok között nincs anyagáramlás és a bizományosoknak egyedi vevőik vannak. Az alapmodell D5 kiegészítésével a bizományosok között lehetőség van az anyagáramlás megvalósítására. Az alapmodell D6 kiegészítésében a bizományosok vevői kapcsolatrendszere kombinálható. A D4-D6 modell a D4 alapmodell és kiegészítéseinek összes anyagáramlási kapcsolatait tartalmazza.

- D7, D8, D9, D7-D9: Ezen disztribúciós modellek esetén a központi bizományba adó logisztikaiés gyártóüzem közvetlenül egy központi elosztóraktáron keresztül szállítja a bizományosoknak a termékeket (centralizált, központi raktározás). Mivel egy elosztó központi raktárban valósul meg a raktározás, így a raktár megfelelő működése érdekében komplex anyag- és információáramlási kapcsolat szükséges a központi elosztó raktár és a bizományosok között. Előnye, hogy csak egy központi raktár müködtetését kell megvalósítani, ugyanakkor hátránya, hogy az összes bizományosi és vevői igényt innen kell tudnia kezelni a rendszernek. A D7 alapmodellben a bizományosok között nincs anyagáramlás és a bizományosoknak egyedi vevőik vannak. Az alapmodell D8 kiegészítésével a bizományosok között lehetőség van az anyagáramlás megvalósítására. Az alapmodell D9 kiegészítésében az bizományosok vevői kapcsolatrendszere kombinál- 
ható. A D7-D9 modell a D7 alapmodell és kiegészítéseinek összes anyagáramlási kapcsolatait tartalmazza.

- D10, D11, D12, D10-D12: Ezen típusú disztribúciós modellek esetében az elosztás közvetlenül a központi bizományba adó logisztikai és gyártó üzemből történik (közvetlen elosztás). A központi bizományba adó logisztikai és gyártóüzemben nincs túlzott raktározási tevékenység, emiatt a bizományosi disztribúciós raktárakban megvalósuló raktározási tevékenységgel kiegészülve kell a folyamatos bizományosi és vevői igényeket kielégítő mennyiségeket tárolni, amelyek sokszor a bizományosi eladó térben lévő tároló nagyságában valósul meg. Ez egy fejlettebb anyag- és információáramlási kapcsolatot igényel, mind a központi bizományba adó logisztikaiés gyártóüzem mind a bizományosok és vevők között. A D10 alapmodellben a bizományosok között nincs anyagáramlás és a bizományosoknak egyedi vevőik vannak. Az alapmodell D11 kiegészítésével a bizományosok között lehetőség van az anyagáramlás megvalósítására. Az alapmodell D12 kiegészítésében az bizományosok vevői kapcsolatrendszere kombinálható. A D10-D12 modell a D10 alapmodell és kiegészítéseinek összes anyagáramlási kapcsolatait tartalmazza.

- D13, D14, D15, D13-D15: Ezen típusú disztribúciós modellek esetén az előző négy modell vegyes felhasználásából épül fel (vegyes elosztási rendszer). Vannak olyan bizományosok, akik közvetlenül kapják a termékeket a bizományba adótól, vannak olyan bizományosok, akik egyedi raktáron közvetlenül kapják a pótlandó termékeket és vannak olyan bizományosok, amelyek különböző csoportokba kerülnek beosztásra és ezek a csoportok egy-egy raktáron keresztül kapják a pótlandó termékeket. A D13 alapmodellben a bizományosok között nincs anyagáramlás és a bizományosoknak egyedi vevőik vannak. Az alapmodell D14 kiegészítésével a bizományosok között lehetőség van az anyagáramlás megvalósítására. Az alapmodell D15 kiegészítésében a bizományosok vevői kapcsolatrendszere kombinálható. A D13-D15 modell a D13 alapmodell és kiegészítéseinek összes anyagáramlási kapcsolatait tartalmazza.

- Az általam meghatározott disztribúciós modellváltozatok D1, D3, D4, D6, D7, D9, D10, D12, D13, D15 változatai univerzálisnak tekinthetők, ugyanakkor megítélésem szerint a D2, D1-D3, D5, D4-D6, D8, D7-D9, D11, D10-D12, D14, D13-D15 változatok a bizományosi értékesítésü hálózatok specifikus esetei. Összességében elmondható, hogy a bizományosi és vevői oldalról 20 féle disztribúciós anyaáramlási modellt különböztethetünk meg.

\section{Visszaszállítási modellek ismertetése:}

A 6. ábra a visszaszállítási modellváltozatokat mutatja, melynek jelölésrendszere a következő:

- $R_{f}: \quad$ az f. raktár $(\mathrm{f}=1,2 \ldots \mathrm{d})$,

- $E_{h}$ : a h. visszaszállítási csoport raktár $(\mathrm{h}=1,2 \ldots \mathrm{g})$,

- EK: központi visszaszállítási raktár,

$B i z_{j}$ : a j. bizományos $(\mathrm{j}=1,2 \ldots \mathrm{m})$.

A 6. ábrán látható modelleknél 2-féle színű nyíl található. A fekete színű nyilak az alapmodell anyagáramlását jelölik, melynek további kiegészített változata piros színủ nyíllal került jelölésre. 
V1, V2

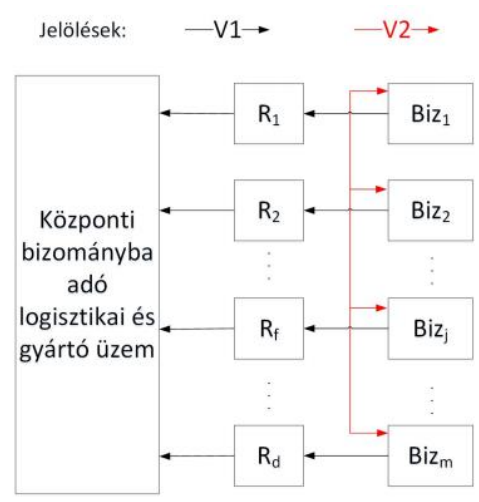

V5, V6

Jelölések: $\quad-\mathrm{V} 5 \rightarrow \quad-\mathrm{V} \rightarrow$

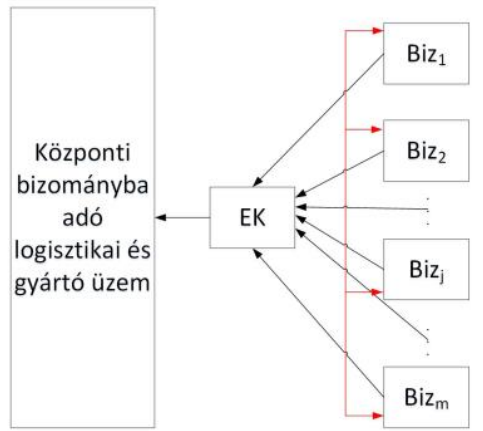

V3, V4

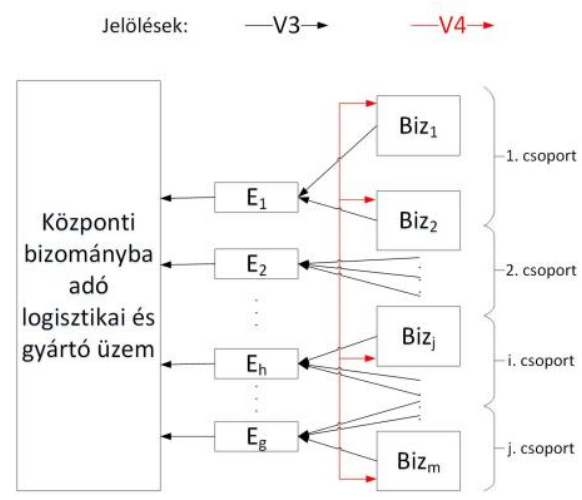

V7, V8

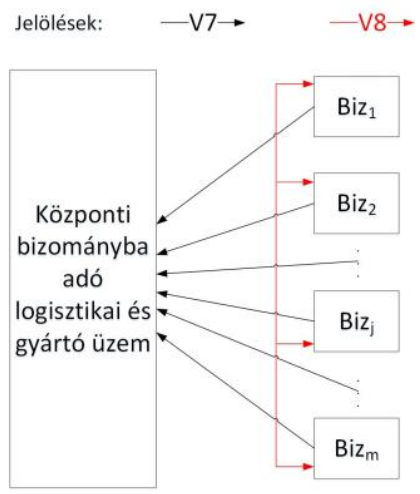

V9, V10

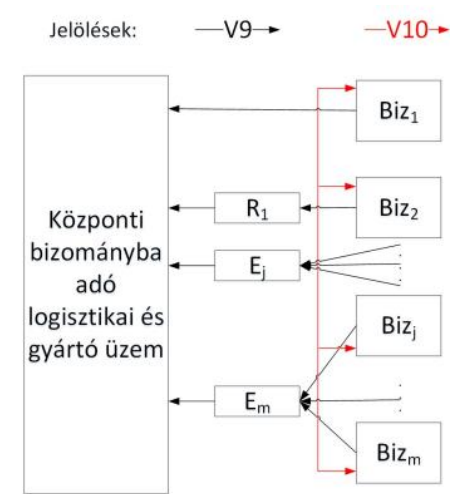

6. ábra. Visszaszállitási modell változatok [Forrás: Saját szerkesztés]

- V1, V2: Ezen típusú visszaszállítási modelleknél, minden egyes bizományos külön egyedi vis-szaszállítási raktárhoz van hozzárendelve (egyedi, decentralizált raktározás) és ezen keresztül 
zajlik a visszaszállítási anyagáramlás a központi bizományba adó-gyártó üzem felé. A modell előnye, hogy a bizományosok a visszaszállítási mennyiségeket egy egyedi, hozzájuk rendelt raktárban tudják kezelni, ugyanakkor hátránya a rendszernek, hogy számos raktárat kell üzemeltetni. A V1 alapmodellben a bizományosok között nincs anyagáramlás. Az alapmodell V2 kiegészítésével a bizományosok között lehetőség van az anyagáramlás megvalósítására, így a központ ki tud jelölni egy egyedi raktárat, ahová az összes visszaérkező terméket raktározni tudja.

- V3, V4: Ezen típusú visszaszállítási modellek esetén a bizományosok bizonyos szempontok alapján (elhelyezkedés, termékstruktúra, stb.) egy adott visszaszállítási raktárhoz vannak rendelve, vagyis egy-egy visszaszállítási raktárhoz bizományosok adott csoportja tartozik (csoportos raktározás). Egy csoportos raktár kapacitását visszaszállított termékek tekintetében több bizományos között kell elosztani. A raktárak száma kevesebb, mint a V1 és V2 modellek esetén. Ez összességében a müködtetésnél költségmegtakarítást jelenthet. A V3 alapmodellben a bizományosok között nincs anyagáramlás. Az alapmodell V4 kiegészítésével a bizományosok között lehetőség van az anyagáramlás megvalósítására, így a központ ki tud jelölni egy csoportos raktárat, ahová az összes visszaérkező terméket raktározni tudja.

- V5, V6: Ezen visszaszállítási modellek esetén a bizományosoktól érkező visszaszállított termékeket egy központi raktárba szállítják be (centralizált, központi raktározás). A központi raktárat a bizományosok közösen használják, a raktár megfelelö müködése érdekében komplex anyagés információáramlási kapcsolat szükséges a központi raktár és a bizományosok között. Előnye, hogy csak egy raktár müködtetését kell megvalósítani, ugyanakkor hátránya, hogy az összes bizományosi visszaszállítási készletet kezelni kell tudni. A V5 alapmodellben a bizományosok között nincs anyagáramlás. Az alapmodell V6 kiegészítésével a bizományosok között lehetőség van az anyagáramlás megvalósítására, így a visszaszállításra szánt termékeket a bizományosok között tudja csoportosítani, akár egy nagyobb raktárral rendelkező bizományosnál tárolni tudja egy bizonyos mennyiségig.

- V7, V8: Ezen típusú visszaszállítási modellek esetében a visszaszállítás közvetlenül a központi bizományba adó logisztikai és gyártó üzembe történik (közvetlen visszaszállítás). Ez egy fejlettebb anyag- és információáramlási kapcsolatot igényel, mind a központi bizományba adó logisztikai és gyártóüzem mind a bizományosok és vevők között. A V7 alapmodellben a bizományosok között nincs anyagáramlás. Az alapmodell V8 kiegészítésével a bizományosok között lehetőség van az anyagáramlás megvalósítására, így a visszaszállításra szánt termékeket a bizományosok között tudja csoportosítani, akár egy nagyobb raktárral rendelkező bizományosnál tárolni tudja ezen termékeket egy bizonyos mennyiségig.

- V9, V10: Ezen típusú disztribúciós modellek esetén az előző négy modell vegyes felhasználásából épül fel (vegyes visszaszállítási rendszer). Vannak olyan bizományosok, akiktől közvetlenül áramlanak vissza a termékeket, vannak olyan bizományosok, akiktől saját raktáron közvetlenül áramlanak vissza a termékeket és vannak olyan bizományosok, amelyek különböző csoportokba kerülnek beosztásra és ezektől a csoportoktól egy-egy raktár felhasználásával valósítják meg a visszaszállítási anyagáramlást. A V9 alapmodellben a bizományosok között nincs anyagáramlás. Az alapmodell V10 kiegészítésével a bizományosok között lehetőség van az anyagáramlás megvalósítására, így a visszaszállítási kapacitások egyedi, csoportos, központi raktárba eloszthatóak, vagy egy bizományoshoz átszállítva a visszaszállításra kijelölt termékeket, azok közvetlenül a központba visszaszállíthatóak. 
Bizonyos területektől (pl. gyógyszeripar) eltérően specifikum lehet a késztermék újrahasznosítási célból való átszállítása a bizományosok között és/vagy elosztó raktárakba és/vagy központi gyártó és bizományba adó telephelyre. Bizományosi oldalról 10 féle visszaszállítási anyagáramlási modellt különböztethetünk meg.

Az előzőekben feltárt modellváltozatok esetében beszerzési modellváltozatoknál 5-féle, bizományosi disztribúciós modellváltozatoknál 20 -féle, valamint a bizományosi visszaszállítási modellváltozatoknál 10-féle változatot tártunk fel. Ezen változatok kombinációjából 1000-féle különböző 4 szintű bizományosi ellátási lánc írható le.

Az információ-áramlási kapcsolatok rendkívül szerte ágazóak. Általánosságban elmondható, hogy a bizományba adó és a vevő, valamint az alapanyag beszállító és a bizományos, a bizományosok között, valamint a bizományos és a vevő között nem alakulhat ki információáramlási kapcsolat, ugyanakkor a többi objektum relációiban ez adott esettől függően létrejöhet. Természetesen eseti jelleggel létrejöhetnek ettől eltérő információáramlási kapcsolatok is, ugyanakkor ezek nem relevánsak, így a kidolgozott modellváltozatok ezeket nem tartalmazzák.

\section{4. Összefoglalás}

A közleményben meghatároztuk a bizományosan értékesítő étrend-kiegészítőket gyártó vállalatok központi gyártással, valamint ingajárat formájában történő szállítással kialakított ellátási láncának típusait, mely ellátási láncokól kiindulva különféle optimalizálási eljárások, módszerek dolgozhatók ki a hatékonyabb müködés érdekében. Kiemelendő, hogy a bemutatásra került kutatás eredményeként feltárt alternatívák elősegítik a bizományos értékesítésủ étrend-kiegészítőket gyártó vállalatok által alkalmazott ellátási lánc típusok felülvizsgálatát. A feltárásra került ellátási lánc típusoknál fontos szerepet kapott az újrahasznosítási célból történő lejárt készletek visszaszállítási lehetőségei is a központi logisztikai és gyártóüzemnek. A feltárt modellek esetén nagy figyelmet kell fordítani a visszaszállításból eredő lehetőségekre, mivel napjainkban a vállalati életben egyre nagyobb szerepet kap az újrahasznosítás kérdése.

\section{Irodalom}

[1] Sundmaeker, H. (2016). Accelerating system development for the food chain: A portfolio of over 30 projects, aiming at impact and growth. International Journal on Food System Dynamics Open Access, 7(4), 371-381. https://doi.org/10.18461/pfsd.2016.1639

[2] Halweil, B. (2007). Still no free lunch: Nutrient levels in U.S. food supply eroded by pursuit of high yields. Organic-center report. https://ucanr.edu/datastoreFiles/608-809.pdf

[3] Davis D. R., Epp, M. D., Riordan, H. D. (2004). Changes in USDA food composition data for 43 garden crops, 1950 to 1999. Journal of the American College of Nutrition, 23, 669-682. https://doi.org/10.1080/07315724.2004.10719409

[4] Grand View Research Dietary Supplements Market Size Analysis Report by Ingredient (Botanicals, Vitamins), By Form, By Application (Immunity, Cardiac Health), By End User, By Distrib ution Channel, And Segment Forecasts, 2019-2025, p. 120. Report ID: 978-1-68038919-7

[5] Elodie, A., Nantaporn, R. (2011). Consignment contracts with retail competition. Mechanical and Industrial Engineering, University of Illinois, Chicago, United States, https://doi.org/10.1016/j.ejor.2011.05.059 
[6] Kamarási, V., Mogyorósy, G. (2015). Szisztematikus irodalmi áttekintések módszertana és jelentősége. Segítség a diagnosztikus és terápiás döntésekhez. Orvosi Hetilap, 156(38), 15231531. http://dx.doi.org/10.1556/650.2015.30255

[7] Zhihui, W., Dongyan, C., Hui, Y. (2017). Coordination of a supply chain with consumer return under vendor-managed consignment inventory and stochastic demand. International Journal of Production Research, 45, 502-516. https://doi.org/10.1080/03081079.2015.1106736

[8] Jun, R., Yunzeng, W. (2010). Consignment contracting: Who should control inventory in the supply chain? European Journal of Operational Research, 201, 760-769. https://doi.org/10.1016/j.ejor.2009.04.006

[9] Abolfazl, G., Mostafa, K., Seyed, A. H. S. (2019). An integrated multi-product, multi-buyer supply chain under penalty, green, and quality control polices and a vendor managed inventory with consignment stock agreement: The outer approximation with equality relaxation and augmented penalty algorithm. Applied Mathematical Modelling, 69, 223-254. https://doi.org/10.1016/j.apm.2018.11.035

[10] Agnieszka, K. (2006). Outsourcing as the conception of modern management. The Challenges for Reconversation, Innovation - Sustainability - Knowledge Management, Chestochowa, Poland. https://doi.org/10.3390/su10010210

[11] Chikán, A. (1999). Az értékteremtö folyamat. Értékteremtő folyamatok menedzsmentje. Budapest, Aula Kiadó.

[12] Körmendi, L., Pucsek, J. (2009). A logisztika elmélete és gyakorlata. SALDO Zrt. Kiadó, ISBN: 9789636382759.

[13] Lynch, C. F. (2000). Logistics outsourcing: a management guide. Council of Logistics Management Publications, USA, ISBN: 978-0365265344

[14] KPMG CONSULTING KFT. (2003). Logisztikai Outsourcing Magyarországon. Tanulmány.

[15] Mishra, B. K., Raghunathan, S. (2004). Retailer vs. vendor managed inventory and brand competition. Management Science, 50, 445-457. https://doi.org/10.1287/mnsc.1030.0174

[16] Siraj, K. Z., Mohamad, Y. J., Simone, Z. (2016). The consignment stock case for a vendor and a buyer with delay-in-payments. Computers and Industrial Engineering, 98, 333-349. https://doi.org/10.1016/j.cie.2016.06.010

[17] Breite, R., Koskinen, K. U.: The potential for achieving efficient vendor managed inventory process, 2007 IPSERA Conference, pp. 1-10. https://doi.org/10.1073/ispe.0701890104

[18] Yunzeng, W., Li, J., Zou-jun, S. (2004). Channel performance under consignment contract with revenue sharing. Management Science, INFORMS, 50(1), 34-47.

https://doi.org/10.1287/mnsc.1030.0168

[19] Hesham, K. A., Ahmed, M. A. (2017). A supply chain model with vendor-managed inventory, consignment, and quality inspection errors. International Journal of Production Research, 55, 5706-5727. https://doi.org/10.1080/00207543.2017.1330566

[20] Hemmati, M., S.M.T. Fatemi, G., Mohsen, S. S. (2017). Vendor managed inventory with consignment stock for supply chain with stock- and price-dependent demand. International Journal of Production Research, 55, 5225-5242.

https://doi.org/10.1080/00207543.2017.1296203

[21] Teyarachakul, S., Tang, K., Tarakci, K. (2007). Learning effects on maintenance outsourcing. European Journal of Operational Research, Elsevier, 192(1), 138-150. https://doi.org/10.1016/j.ejor.2007.09.016 
[22] Wei, H., Jianbin, L. (2012). Disposing the leftovers under the consignment contract with revenue sharing: Retailer vs supplier. Journal of Systems Science and Complexity, 25, 262-274. https://doi.org/10.1007/s11424-011-9063-7

[23] Országgyülési Hivatal (2020). Gyógyszerhulladék kezelés az Európai Unióban.

[24] Wang, Y. Z., Jiang, L., Shen, Z. J. (2004). Channel performance under consignment contract with revenue sharing. Management Science, 50, 34-47. https://doi.org/10.1287/mnsc.1030.0168

[25] Zavanella, L., Zanoni, S. (2009). A one-vendor multi-buyer integrated production-inventory model: The 'Consignment Stock' case. International Journal of Production Economics, 118(1), 225-232. https://doi.org/10.1016/j.ijpe.2009.10.027

[26] Li, S., Zhu, Z., Huang, L. (2009). Supply chain coordination and decision making under consignment contract with revenue sharing. International Journal of Production Economics, 120(1), 88-99. https://doi.org/10.1016/j.ijpe.2008.07.015

[27] Daniela, A., Maria, G. S. (2005). Distribution network design: New problems and related models. European Journal of Operational Research, 165(3), 610-624. https://doi.org/10.1016/j.ejor.2003.04.009

[28] Claassen, M. J. T., Weele, A. V., Raaij, E. M. V. (2008). Performance outcomes and success factors of vendor managed inventory (VMI). Supply Chain Management: An International Journal, 13, 406-414. https://doi.org/10.1108/13598540810905660

[29] Zanoni, S., Mazzoldi, L., Jaber, M. Y. (2014). Vendor-managed inventory with consignment stock agreement for single vendor-single buyer under the emission-trading scheme. International Journal of Production Research, 52(1), 20-31.

https://doi.org/10.1080/00207543.2013.812812

[30] Chen, J. M., Lin, I. C., Cheng, H. L. (2010). Channel coordination under consignment and vendor-managed inventory in a distribution system. Transportation Research Part E: Logistics and Transportation Review, 46(6), 831-843. https://doi.org/10.1016/j.tre.2010.05.007

[31] Bieniek, M. (2018). Channel performance under vendor managed consignment inventory contract with additive stochastic demand. Statistics in TransitionOpen Access, 19(3), 551-561. https://doi.org/10.21307/stattrans-2018-030

[32] Hariga, M., Gumus, M., Daghfous, A., Goyal, S. K. (2013). A vendor managed inventory model under contractual storage agreement. Computers and Operations Research, 40(8), 21382144. https://doi.org/10.1016/j.cor.2013.03.005

[33] Zahran, S. K., Jaber, M. Y., Zanoni, S. (2017). Comparing different coordination scenarios in a three-level supply chain system. International Journal of Production Research, 55(14), 40684088. https://doi.org/10.1080/00207543.2016.1249431

[34] Szentesi, Sz., Illés, B., Cservenák, Á., Skapinyecz, R., Tamás, P. (2021). Multi-level optimization process for rationalizing the distribution logistics process of companies selling dietary supplements. PROCESSES, Volume 9(9), pp.:1480, 27 p., IF: 2,847., https://doi.org/10.3390/pr9091480 